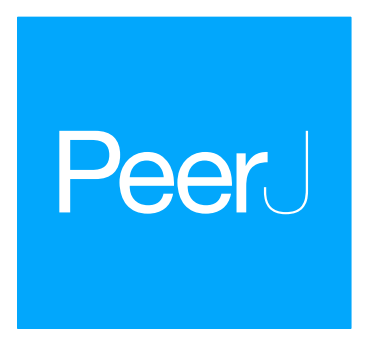

Submitted 19 October 2015

Accepted 22 January 2016

Published 15 March 2016

Corresponding author

Mar Sobral,

sobral.bernal.mar@gmail.com

Academic editor

David Roberts

Additional Information and Declarations can be found on page 11

DOI 10.7717/peerj.1685

Copyright

2016 Sobral et al.

Distributed under

Creative Commons CC-BY 4.0

OPEN ACCESS

\section{Flower color preferences of insects and livestock: effects on Gentiana lutea reproductive success}

\author{
Mar Sobral $^{1}$, María Losada ${ }^{1}$, Tania Veiga ${ }^{1}$, Javier Guitián², José Guitián ${ }^{1}$ \\ and Pablo Guitián ${ }^{2}$ \\ ${ }^{1}$ Departamento de Bioloxía Celular e Ecoloxía/Facultade de Bioloxía, Universidade de Santiago de Compostela, \\ Santiago de Compostela, Spain \\ ${ }^{2}$ Departamento de Botánica/Facultade de Bioloxía, Universidade de Santiago de Compostela, \\ Santiago de Compostela, Spain
}

\section{ABSTRACT}

Angiosperms diversification was primarily driven by pollinator agents, but nonpollinator agents also promoted floral evolution. Gentiana lutea shows pollinator driven flower color variation in NW Spain. We test whether insect herbivores and livestock, which frequently feed in G.lutea, play a role in G. lutea flower color variation, by answering the following questions: (i) Do insect herbivores and grazing livestock show flower color preferences when feeding on G. lutea? (ii) Do mutualists (pollinators) and antagonists (seed predators, insect herbivores and livestock) jointly affect G. lutea reproductive success? Insect herbivores fed more often on yellow flowering individuals but they did not affect seed production, whereas livestock affected seed production but did not show clear color preferences. Our data indicate that flower color variation of G. lutea is not affected by insect herbivores or grazing livestock.

Subjects Animal Behavior, Conservation Biology, Ecology, Evolutionary Studies, Plant Science Keywords Flower color variation, Gentiana lutea, Insect herbivory, Large mammal herbivory, Herbivore preferences

\section{INTRODUCTION}

Despite pollinators being considered the principal driver of floral diversification and speciation (Bradshaw \& Schemske, 2003; Herrera, Castellanos \& Medrano, 2006; Whittall \& Hodges, 2007; Van der Niet, Peakall \& Johnson, 2014), non-pollinator agents also interact with plants and promote floral evolution (Strauss \& Whittall, 2006; Andersson, 2008). This is the case with antagonist animals, such as herbivores, which damage plants as a result of resources extraction (Strauss \& Whittall, 2006; Whittall \& Carlson, 2009), affecting fitness and, therefore, potentially causing natural selection on plant traits (Wise \& Hébert, 2010; Agrawal et al., 2012; De Jager \& Ellis, 2014).

Plant reproductive success can be shaped by the balance between mutualistic and antagonistic interactions which may maintain floral trait variation (Herrera et al., 2002; Lavergne, Debussche \& Thompson, 2005; McCall \& Irwin, 2006; Bartkowska \& Johnston, 2012). Herbivory can have a negative effect on plant fitness in a greater or lesser extent depending on pollinator presence or absence (Herrera, 2000; Herrera et al., 2002), and the positive effect exerted by pollinators may depend on herbivore presence 
(Gómez, 2003; Gómez, 2005a). Thus, phenotypic variation of a floral trait, such as flower color, can result from the balance between the positive selection pressures exerted by pollinators and seed dispersers, and the negative selection pressures exerted by herbivores or seed predators (Herrera, 2000; Herrera et al., 2002; Irwin et al., 2003; Asikainen \& Mutikainen, 2005; Frey, 2004; Strauss, Irwin \& Lambrix, 2004; Andersson, 2008; Bartkowska $\&$ Johnston, 2012). Selective pressures exerted by abiotic factors (Galen, 2000; Warren \& Mackenzie, 2001; Streisfeld \& Kohn, 2007) and historical processes or genetic drift (MitchellOlds, Willis \& Goldstein, 2007) may also influence phenotypic variation.

Invertebrate herbivory (mainly insects and gastropods) negatively affects plant fitness causing natural selection on plant traits, including floral traits, such as flower color (Fineblum \& Rausher, 1997; Frey, 2004; Whittall \& Carlson, 2009; Bartkowska \& Johnston, 2012). Additionally, vertebrate herbivory (typically represented by large mammal herbivores) affect plant fitness and community composition (Herrera, 1984; Agustine \& McNaughton, 1998; Knight, 2003; Gómez, 2005b; Allsup, 2014). Interaction with mammals can also have a positive effect for the plants. Reproductive success of many flowering plant species relies on browsing ungulates activity, since they play an essential role if ungulates act as seed dispersal agents within plant communities (for example, Herrera, 1984; Herrera, 2000). Thus, the effect of mammal herbivory can be either positive, if they act as seed dispersal agents, or negative if they act as herbivores. Many plant communities interact not only with wild fauna but also with domesticated mammals. Domesticated ungulates such as cattle, horses and sheep often feed on wild plant populations (for example during transhumance practices) potentially exerting natural selection on them.

The type and strength of selection exerted on plant attributes depend on herbivore preferences during foraging (Agustine \& McNaughton, 1998; Asikainen \& Mutikainen, 2005; Agrawal, Lau \& Hambäck, 2006). Livestock could discriminate between flower color morphs (Phillips \& Lomas, 2001), and thus might be able to show color preferences. But, even if livestock could not detect flower color differences, it still may differentially feed on a particular color morph if it shows preferences for any trait correlated with flower color (see Lande \& Arnold, 1983). As it could be the case for some herbivory defenses which are known to be correlated with floral pigments (Simms \& Bucher, 1996).

The effect of livestock (negative or positive) is expected to be stronger than the exerted by insect herbivores or pollinators due to the amount of damage or seed dispersal that large vertebrates are able to exert. Thus, it is necessary to take their effect into account in order to have a holistic view of the biotic forces exerting selective pressures on traits such as floral color (Johnson, Campbell \& Barrett, 2015).

Although it has been long recognized that both pollinators and herbivores play an important role on plant evolution (Ehrlich \& Raven, 1964), their effects are usually studied independently and under different scopes (Johnson, Campbell \& Barrett, 2015). Moreover, the effects of grazing mammals on flower traits have been disregarded (but, see Juenger \& Bergelson, 1997; Gómez, 2003; Gómez et al., 2009; Agren et al., 2013), and the potential effects of domesticated mammal herbivores on floral traits are unknown. Here we explore for the first time the simultaneous effect of wild and domesticated animals on plant traits, particularly regarding their potential effect on flower color variation. 
Gentiana lutea flower color varies continuously from orange to yellow within and among populations in NW Spain (Sobral et al., 2015)—where livestock interacts with plant communities (see Blanco-Fontao, Quevedo \& Obeso, 2011) and commonly feed on G. lutea. This corolla color variation has a genetic basis (Zhu et al., 2002; Zhu et al., 2003) and is not related to abiotic factors such as radiation, altitude, temperature or rainfall (Veiga et al., 2015a). Two flower color varieties are described (Lainz, 1982; Renobales, 2003) and a partial hybridization barrier exists between the yellow G. lutea var. aurantiaca and the orange $G$. lutea var. lutea (Losada et al., 2015). G. lutea is strongly dependent on pollinators which, together with seed predators, show flower color preferences causing selection on flower color (Losada et al., 2015; Veiga et al., 2015b).

Here we test if insect herbivores-mainly adults belonging to Orthopthera and Coleoptera orders, and larvae from different insect groups-and large mammal domesticated herbivores (local extensive livestock, mainly cows and horses) affect flower color variation in Gentiana lutea-while having into account the effect of pollinators and seed predators. For this purpose, the following questions were formulated: (i) Do insect herbivores and livestock show flower color preferences when feeding on G. lutea? (ii) Do mutualists (pollinators) and antagonists (seed predators, insect and livestock) jointly affect G. lutea reproductive success?

\section{MATERIALS \& METHODS}

\section{Study area}

Our study area covered the distribution of Gentiana lutea in the Cantabrian Mountains, NW Spain (see Fig. 1). In 2010, we visited 8 populations (Cebreiro, Ancares, Leitariegos, Torrestío, Ventana, San Isidro, Señales and San Glorio) and 12 in 2011 (Queixa, San Mamede, Loureses and Pontón were new). All studied populations were haphazardly selected along a $230 \mathrm{~km}$ longitudinal gradient from the San Mamede population $\left(42^{\circ} 12^{\prime} \mathrm{N}, 7^{\circ} 30^{\prime} \mathrm{W}\right.$; at the western limit) to the San Glorio population $\left(43^{\circ} 04^{\prime} \mathrm{N}, 4^{\circ} 45^{\prime} \mathrm{W}\right.$; at the eastern limit), and localized at high altitudes from 1,100 $\mathrm{m}$ to 1,700 m.a.s.l., on grassy pastures and hillsides used extensively by local livestock. For this research, we received a field permit from the Environmental Territorial Service of León, Territorial Delegation of Government of Spain, Regional Government of Castilla and León (ID:12_LE_325_RNA_PuebladeLillo_INV; Reference: 06.01.013.016/ROT/abp; File number: AEN/LE/103/12).

\section{Plant species}

Gentiana lutea (Gentianaceae) is a rhizomatous perennial herb distributed throughout central and southern European mountains, living at montane and sub-alpine levels (approximately from 700 to 2,000 m.a.s.l.) and mainly associated with livestock grazing grasslands (Hesse, Rees \& Müller-Schärer, 2007; Anchisi et al., 2010). This is a long-lived geophyte, which usually develops one unbranched stout stem (rarely two or three) measuring up to $190 \mathrm{~cm}$ tall; and shows a basal rosette formed from lanceolate-elliptic leaves measuring 190-350 ×55-150 mm (Renobales, 2012). Fertile stems bloom in summer (June-July), and show several tens of bisexual and actinomorphic flowers grouped in pseudo-whorls. Flowers present a bicarpellate ovary fixed over a split calix, a stigma with 


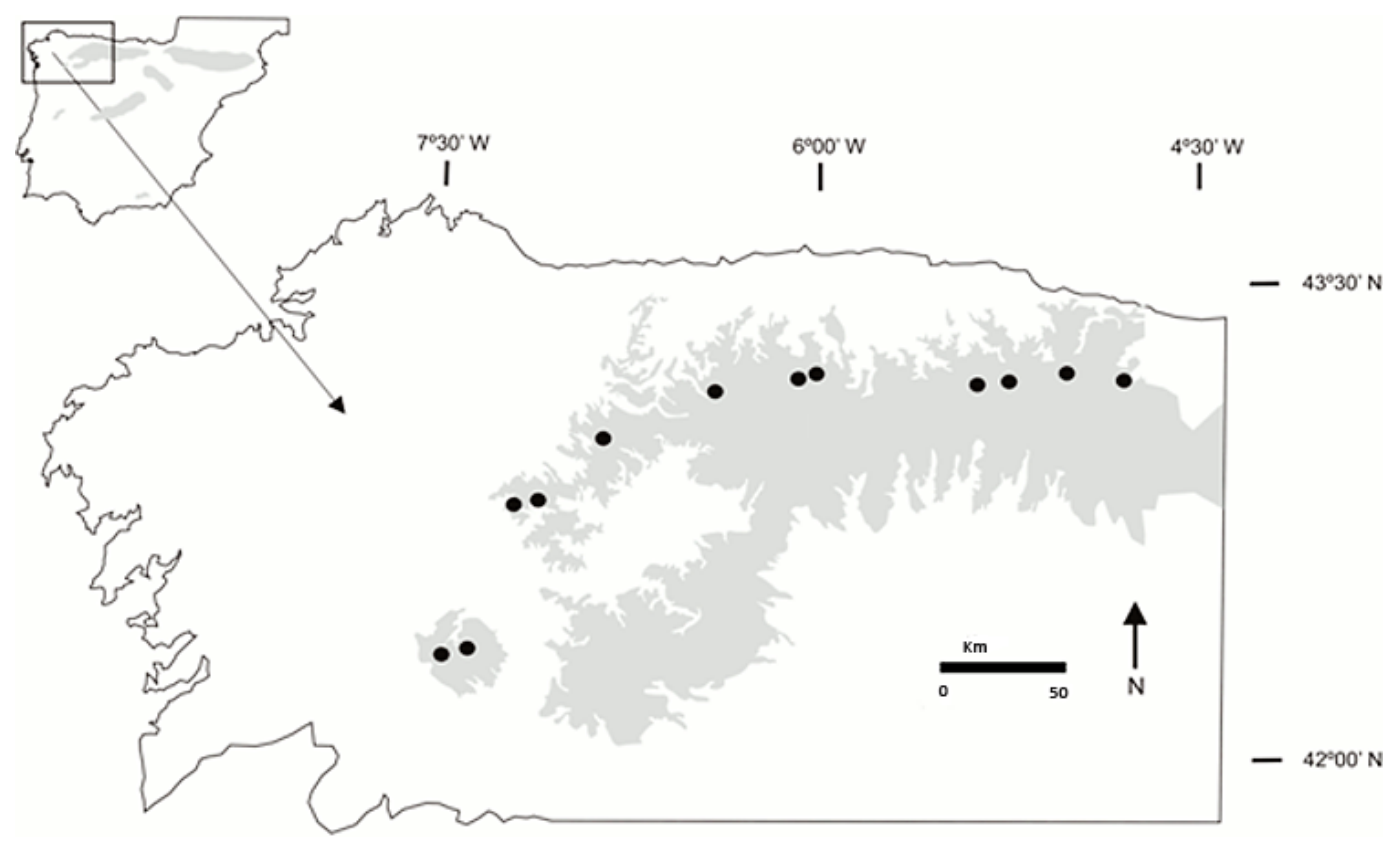

Figure 1 Location of the Gentiana lutea populations sampled. The shaded region indicates the distribution of G. lutea in the Cantabrian Mountains, NW Spain. Black dots represent the 12 studied populations (from W to E): San Mamede, Queixa, Loureses, O Cebreiro, Os Ancares, Leitariegos, Torrestío, Ventana, San Isidro, Señales, Pontón and San Glorio.

two lamellae and (4-8) petals fused on the basis. Corollas have an open structure, which facilitates pollinator access (mainly insects belonging to Hymenoptera and Diptera orders) to flower nectaries. Corolla color varies from orange to yellow along the G. lutea distribution range in the Cantabrian Mountains, Spain (Sobral et al., 2015). G. lutea fruits are capsules, which hold a great number of elliptic, flattened and winged seeds, measuring $2.5-4.5 \mathrm{~mm}$, which ripen in summer (Renobales, 2012). Wind is the main seed dispersal agent (Struwe $\&$ Albert, 2002). G. lutea may be considered a toxic species, because it contains relatively high levels of herbivory deterrents (Smit, Ouden \& Müller-Schärer, 2006; Hesse, Rees \& Müller-Schärer, 2007).

\section{Field procedures Plant traits measurement}

In July 2010, during blooming, we measured flower color on ten randomly chosen flowers per plant. In 2011, we measured color on only three flowers per plant because we found that the coefficient of variation for flower color within plants was asymptotic, reaching a plateau after three flowers. Each petal was measured three times. Final color spectrum data for individual plants came from the mean of these three measurements per petal for 10 petals belonging to 10 different flowers in 2010 (30 floral color data per plant in 2010) and three measurements for each of three petals belonging to three different flower in 2011 (nine color data per plant in 2011). We measured floral color in a total of 2,711 flowers belonging to 504 plants across $12 \mathrm{G}$. lutea populations. With the aim of taking into account indirect selection on correlated plant traits (see Veiga et al., 2015b), we also measured the 
stalk height (the height of the stalk from the base of the plant to the top, in $\mathrm{cm}$ ) and the leaf length (the length of the longest basal leaf from the insertion to the tip, in $\mathrm{mm}$ ) in each plant.

Flower color was measured by means of a spectrometer (USB2000+; Ocean Optics, Inc., Dunedin, FL, USA) and the petal color spectra were processed using the SpectraSuite ${ }^{\circledR}$ software (Ocean Optics, Inc., Dunedin, FL, USA). No differences among populations and between color morphs (orange or yellow colors, discernible by human eye) were found in the UV light range in a previous study (see Veiga et al., 2015b). Thus, flower color variation was described by means of the CIELab Colorimetric System (International Commission on Illumination, 2004). This colorimetric system is based on the visible light range of the electromagnetic spectrum and allows for a transformation of the measured reflectance spectrum into three variables, which describe the flower color variation: $L$ (brightness of color, from black to white), $a$ (red color variation, from green to red) and $b$ (yellow color variation, from blue to yellow; see Veiga et al., $2015 b$ for more information on the flower color measurements).

These three flower color variables $(L, a$, and $b)$ were reduced by principal component analysis (PCA). The first principal component (PC1) explained 63\% of variance of $a, b$ and $L$; thus, $\mathrm{PC} 1$ was used as the flower color variable in the statistical analyses. Correlations between the original color variables and PC1 show that low scores in PC1 indicate orange colors and high scores indicate yellow colors.

\section{Insect herbivory}

A total of 162 individual plants were randomly selected before blossom started (June) in each of 8 populations studied in 2010 (Cebreiro, Ancares, Leitariegos, Torrestío, Ventana, San Isidro, Señales and San Glorio). The insect herbivory percentage was quantified visually for all leaves of each plant during flowering (July). For this, we used the scale designed by Dirzo \& Dominguez (1995), which establishes six categories: the first category includes leaves without damage; the second, leaves with 1-6\% of damage; the third, leaves with $6-12 \%$ of damage; the fourth, $12-25 \%$ of damage; the fifth, $25-50 \%$ and the sixth, $50-100 \%$ of damage. With frequencies of leaves in each category of damage, we calculated the index of herbivory per plant: $I H=\left(\Sigma n i^{*} i\right) / N$; where $n$ is the number of leaves in a category, $i$ is the category number and $N$ is the number of leaves per plant.

\section{Livestock herbivory}

Livestock consume parts of the plants including leaves, flowers or fruits and parts of the stalk. First, we tested whether the effect of livestock was a negative herbivory effect or, on the other hand, whether livestock could be considered a G. lutea seed disperser. We examined livestock herbivory during the fruits ripening season (August) establishing two categories: without evidence of livestock herbivory ( 0 or absence) and with evidence of livestock herbivory (one or presence) in 183 plants chosen in 8 populations in 2010 and 288 plants chosen across 12 populations in 2011.

Livestock was observed feeding on G.lutea at the time that it was bearing fruits. During that time (August 2010 and 2011), we collected 63 livestock fecal samples in all 12 G. lutea populations and examined them (40 belonging to cows, 20 to horses and, 3 to sheep). We 
manually inspected the fecal samples in the lab (3 grams per sample) searching for seed presence within livestock pellets. G. lutea seeds found within livestock fecal samples were later examined for germinability. Seeds were distributed on filter paper in petri plates. The state of germination and wetting of the plates were examined on alternate days; the filter paper was removed every 2-3 days to reduce fungal infection. Germination trials lasted for 60 days. Note that we had previously found that after 45 days, $25 \%$ of viable G. lutea's seeds were germinated (Losada et al., 2015).

\section{Effect of mutualist and antagonist interactions on seed production}

When fruits were not yet opened, total number of fruits was counted per plant. Afterwards, 20 fruits were haphazardly collected per individual. Number of viable seeds was counted in each fruit sampled (over 150,000 seeds were counted). G. lutea plants set on average 79 fruits, each with a mean of 63 seeds (Sobral et al., 2015). Thus, each plant sets approximately 5,000 seeds on average; hence total number of seeds set per plant was impractical to count. Total seed number per plant was estimated by multiplying the number of fruits per plant times the average number of viable seeds per fruit. In this study, total seed number (reproductive output) was used as a proxy for plant fitness.

With the aim of understanding the effect that insect and livestock herbivory have on the G. lutea reproductive output, previously published data on pollination success and seed predation of the same marked plants and reproductive seasons (Sobral et al., 2015) were used to incorporate the effects of these ecological interactions into the models. Note that these models used data from eight populations studied in 2010 (Cebreiro, Ancares, Leitariegos, Torrestío, Ventana, San Isidro, Señales and San Glorio) because we did not collect data on insect herbivory in 2011. See Sobral et al. (2015) for methods to recording pollination and seed predation.

\section{Statistical analyses}

Analyses were performed using the SPSS for Windows, version 20.0 (IBM Corp, 2011). Error distribution, link function and model's structure were chosen by means of the AICc criterion starting with saturated models (Burnham \& Anderson, 2002).

\section{Insect preferences for flower color}

In order to study the insect preferences for flower color, we analyzed the data from 104 plants from the 8 populations studied in 2010. We used a generalized linear model (GzLM) in which the explanatory variables were population, flower color, stalk height, leaf length, the flower color ${ }^{*}$ stalk height interaction and the flower color ${ }^{*}$ leaf length interaction; and the per-plant percentage of herbivory was the response variable (Table 1). Note that the herbivory index was transformed into a per-plant percentage of herbivory before analysis and was fitted to a Poisson distribution with a log link function. Population was included as a fixed factor into the models since they were selected following a longitudinal gradient. Additionally, the same model (without the population effect) for each of the studied populations was performed (see Appendix S1). 


\begin{tabular}{|c|c|c|c|c|}
\hline Dependent variable & Factor & Wald Chi-Square & d.f. & $P$ \\
\hline \multirow[t]{6}{*}{ Insect herbivory } & Flower color & 3.876 & 1 & 0.049 \\
\hline & LL & 1.646 & 1 & 0.200 \\
\hline & $\mathrm{SH}$ & 1.013 & 1 & 0.314 \\
\hline & $\mathrm{LL}^{\star}$ Flower color & 0.498 & 1 & 0.481 \\
\hline & SH ${ }^{\star}$ Flower color & 4.887 & 1 & 0.027 \\
\hline & Population & 12.592 & 7 & 0.083 \\
\hline
\end{tabular}

Notes.

Factor codes: LL, Leaf length (mm); SH, Stalk height $(\mathrm{cm})$.

\section{Livestock preferences for flower color}

Some populations present livestock but others do not and populations differ in the average corolla color (Sobral et al., 2015). Therefore, the flower color preferences across the studied range could be merely reflecting the arbitrary livestock presence on different colored populations. Thus, we analyzed the effect of livestock independently for each population. We analyzed the livestock herbivory within populations (419 plants, between 17 and 64 plants per population), using a generalized linear model (GzLM) equivalent to that used in the case of insect herbivores. The explanatory variables were population, flower color, stalk height, leaf length, the flower color ${ }^{*}$ stalk height interaction and the flower color ${ }^{*}$ leaf length interaction (see Appendix S2). Livestock herbivory was fitted to a Binomial distribution with a logit link function.

\section{Effect of mutualist and antagonist interactions on seed production}

We used a generalized linear model (GzLM) to analyze the effect of the ecological interactions (pollination, seed predation, insect herbivory and cattle herbivory) that may affect total seed number (the response variable), used as a proxy for plant fitness. Cattle herbivory (absence $=0$; presence $=1$ ), pollinator visitation rate (No. visits per minute), escape from seed predation (\% fruits not affected by seed predators) and insect herbivory (per-plant percentage of herbivory) were the explanatory variables. We also included the population effect into the model (Table 2). Total seed set was fitted to a Poisson distribution with a log link function; and error distribution, link function and model's structure were chosen by means of the AICc criterion (Burnham \& Anderson, 2002). We used data from 93 plants belonging to 8 populations studied in 2010 (Cebreiro, Ancares, Leitariegos, Torrestío, Ventana, San Isidro, Señales and San Glorio) to perform this model.

\section{RESULTS}

\section{Insect and livestock preferences for flower color}

Insect herbivores showed simultaneous preferences for flower color and stalk height when feeding on Gentiana lutea (Table 1). Overall, these insects preferred to feed upon yellow-flowering individuals (Fig. 2) and this flower color preference depended on stalk 
Table 2 GzLM fitted to analyze $G$. lutea reproductive output (total seed number) and its relationship with the livestock herbivory $(0 / 1)$, the pollinator visitation rate (No. visits/minute), the escape from seed predation (\% fruits not affected by seed predators), insect herbivory (percentage of per-plant herbivory) and the population effect. N, 93 individuals. The statistically significant effects are marked in bold $(P<0.05)$.

\begin{tabular}{llllll} 
Dependent variable & Factor & $\boldsymbol{B}$ & Wald Chi-Square & d.f. & $\boldsymbol{P}$ \\
\hline Total seed number & Cattle Herbivory & $\mathbf{- 0 . 7 4 2}$ & 7.293 & 1 & 0.007 \\
& Pollinator visitation rate & $\mathbf{0 . 0 7 3}$ & 4.569 & 1 & $\mathbf{0 . 0 3 3}$ \\
& Escape seed predation & 0.005 & 2.383 & 1 & 0.123 \\
& Insect Herbivory & -0.002 & 0.293 & 1 & 0.588 \\
& Population & & 16.484 & 7 & $\mathbf{0 . 0 2 1}$ \\
\hline
\end{tabular}

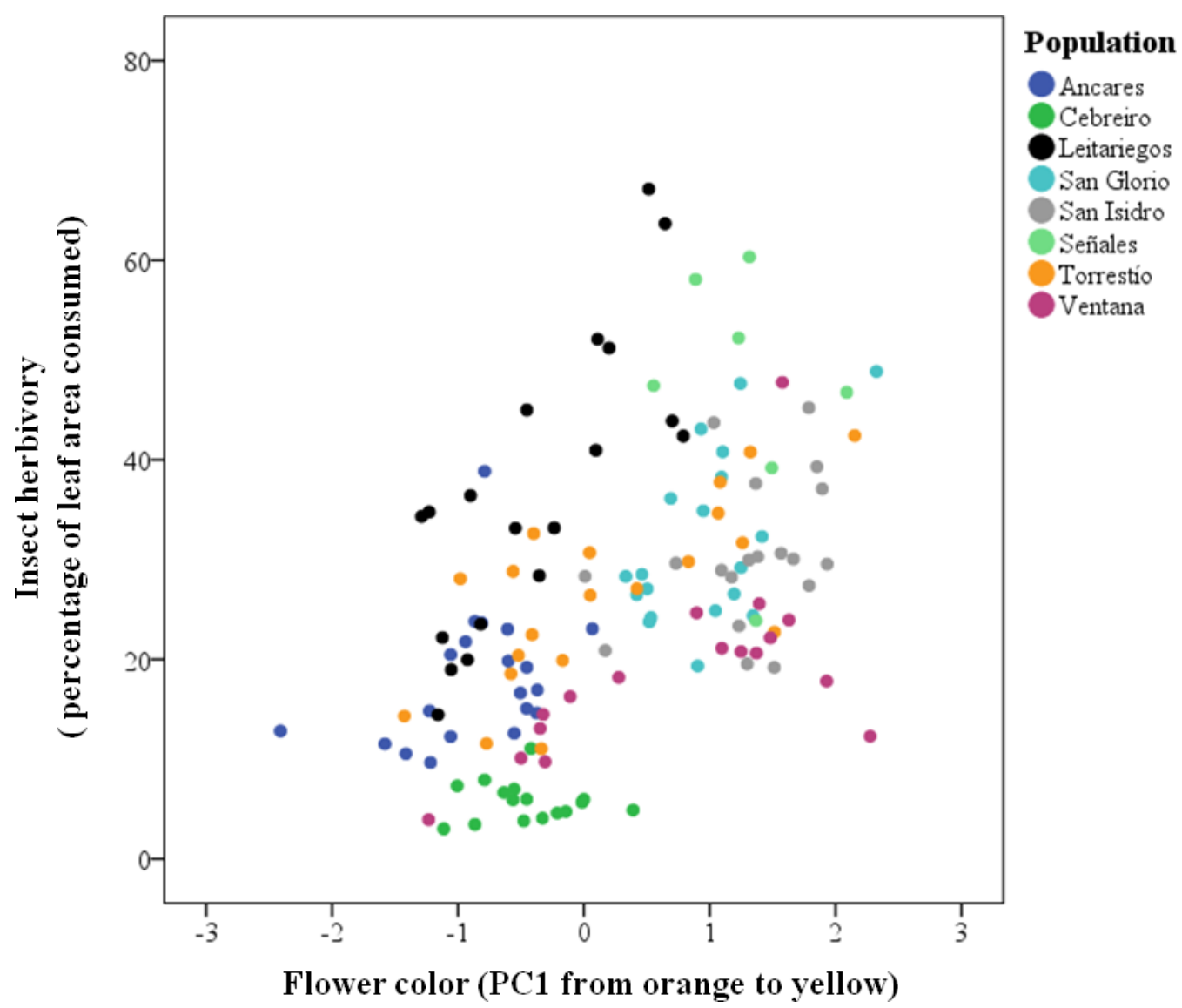

Figure 2 Predicted values of insect herbivory (percentage of eaten leaf area per plant) in relation to G. lutea flower color (PC1). N, 104 individuals, from eight populations studied in 2010.

height, as the significant interaction between these two plant traits suggests. Insects prefer yellow-flowering individuals and, among these, shorter individuals were more herbivorized than longer ones (Table 1 and Fig. 3). The relationship between the intensity of herbivory and the interaction between flower color and other plant traits also happens within some of the populations (see Cebreiro, Torrestío and Ventana populations, Appendix S1). 


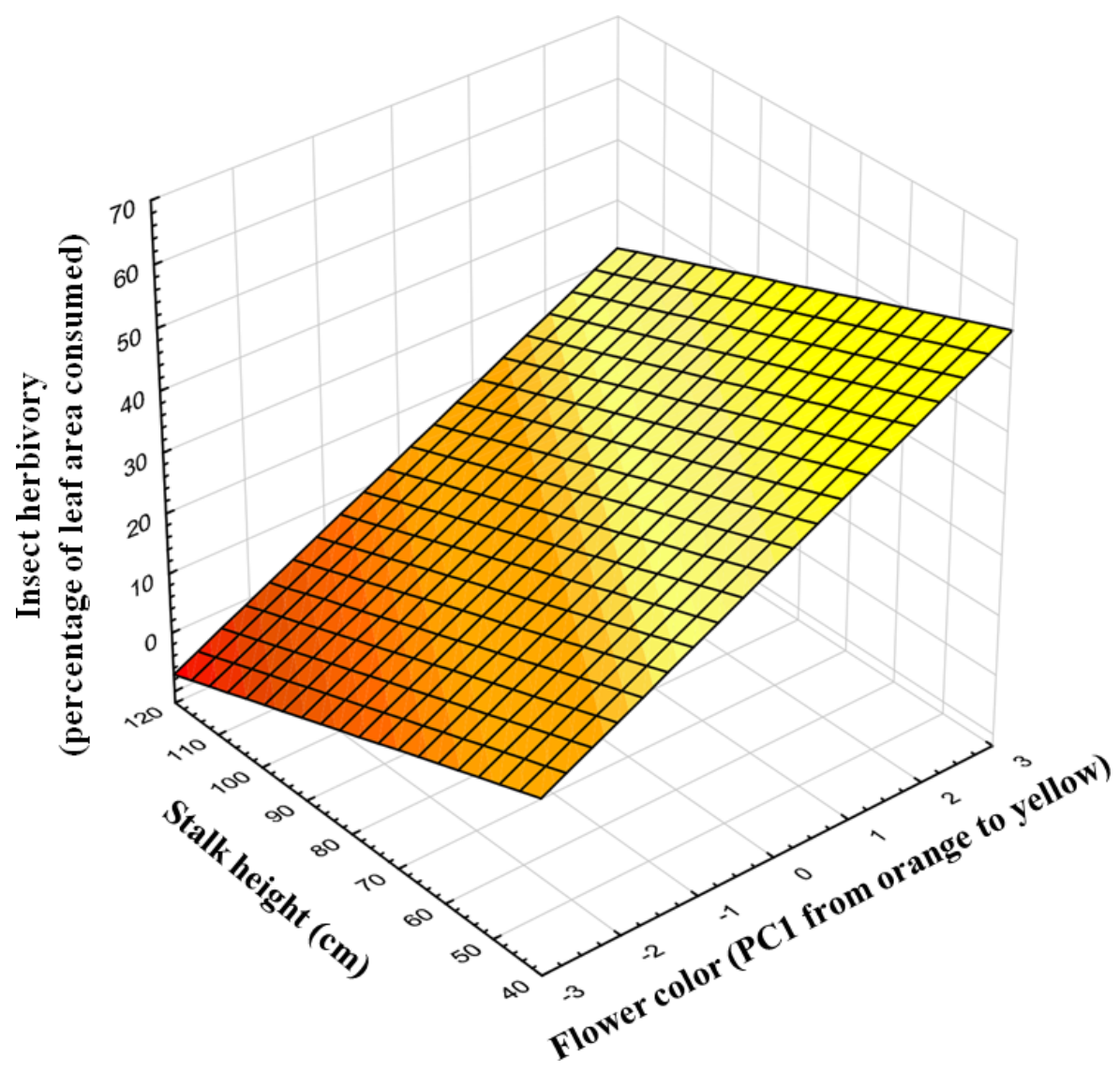

Figure 3 Predicted values of insect herbivory (percentage of eaten leaf area per plant) in relation to flower color (PC1) and correlated stalk height $(\mathbf{c m})$. N, 104 individuals, from 8 populations studied in 2010.

Livestock did not show preferences for flower color within each studied population; although, the probability of livestock herbivory marginally depended on the interaction between flower color and leave length in a population (Cebreiro population; see Appendix S2). Note that significant effects were also not found if the analyses were split by year.

\section{Effect of mutualists and antagonists on G. lutea reproductive success}

After the examination of 63 livestock fecal samples ( 40 cow samples, 20 horse samples and three sheep samples), we found 13 seeds in six different fecal samples (four cow samples and two horse samples) from four different populations. None of these seeds germinated after the 60 days trial, suggesting that seeds did not survive the digestive track of livestock (a previous study showed 25\% germination of G. lutea after 45 days, see Losada et al., 2015). Thus, we rule out the seed disperser role of livestock and consider that the interaction with livestock has a negative effect on G. lutea reproductive success.

Pollinator visitation rate positively affected plant reproductive output and livestock herbivory decreased seed production. Insect herbivory and seed predation did not affect seed production (Table 2). The most important effect on the G. lutea reproductive output turned out to be livestock herbivory, plants which did not suffer livestock herbivory set 
an average of 5,005 $( \pm 416)$ seeds whereas plants eaten by livestock set an average of 1,269 ( \pm 356 seeds). Livestock herbivory affected $G$. lutea reproductive success 10.1 times more than pollinators (see effect sizes, $\beta$ values; Table 2).

\section{DISCUSSION}

Insect herbivores preferred to feed on yellow and short stalk-flowering individuals but livestock did not show flower color preferences along the Gentiana lutea range studied (Table 1 and Fig. 2; Appendix S2). In some G. lutea populations pollinators and seed predators also prefer the yellow morphs (see Veiga et al., 2015b) but the color preferences vary between populations (see Sobral et al., 2015). Pollinators might visit the more herbivorized individuals in some locations whereas, on other locations, pollinator and herbivores might prefer different corolla colors. This is likely to depend on the pollinator and herbivore community composition as well as on the range of color variation in particular populations.

Floral color in G. lutea varies among individuals depending on carotenoids concentration (Zhu et al., 2002). These pigments, which regulate color expression from orange to yellow, are involved in the synthesis of volatile compounds considered to be defenses against insect herbivory (Lakshminarayan, 2013). Alternatively, anthocyanines (which participate in red color expression) may play a dual role, both attracting pollinators and alerting herbivores of a high content of chemical secondary compounds that confer toxicity or, at least make plant tissues difficult to metabolize (Lev-Yadun \& Gould, 2009). The fact that insect herbivores preferred to feed upon yellow-flowering individuals might suggest that yellowish corolla color pigments are related to lower amounts of chemical deterrents than orange pigmentation.

Livestock herbivory negatively affected the reproductive success of G. lutea, whereas pollination had a positive effect on G. lutea's seed output. We found the effect of livestock herbivory on seed production to be stronger than the effect of pollinators (see $\beta$ values, Table 2). The few studies dealing with the joint effect of herbivores and pollinators on floral traits show that selection by herbivores is often (in 70\% of the cases) as strong (or stronger) than selection exerted by pollinators on flowers' characteristics-herbivores potentially affect floral traits as much as pollinators do (see Johnson, Campbell \& Barrett, 2015). Flower color variation in other species is maintained by the balance of selective pressures exerted by mutualisms and antagonisms; for example in Raphanus sativus (McCall et al., 2013), Iris lutescens (Wang et al., 2013), Ursinia calenduliflora (De Jager \& Ellis, 2014) and Geranium thunbergii (Tsuchimatsu, Yoshitake \& Ito, 2014). But, we cannot confirm that either insects or livestock play a role on G.lutea's flower color variation. This is because we found effects of livestock on seed production but not color preferences, and insect herbivores showed color preferences but did not affect seed production. However, insect herbivory also depended on correlations among vegetative traits (such as stalk height or leaf length) and flower color (Table 1; Appendix S1). Thus, if leaf length or stalk height were related to seed production, insects could still be playing an indirect role on the maintenance of flower color variation through pleiotropic effects among correlated plant traits (Fineblum 
\& Rausher, 1997; Herrera et al., 2002; Strauss, Irwin \& Lambrix, 2004; Narbona et al., 2014; Johnson, Campbell \& Barrett, 2015).

Livestock and insect herbivores do not play a role shaping flower color variation in G. lutea (unless through indirect selection). But, pollinators show color preferences and affect G. lutea's fitness. Thus, flower color variation in G. lutea might be originated, or at least reinforced, by the selective pressures exerted by pollinators. Flower color variation in polymorphic species may originate from selection by animals which could favor isolation between different color morphs and cause sympatric diversification. However, other reasons could additionally explain flower color variation; for example, the geographic isolation produced by the Quaternary climatic changes has been identified as the main cause of divergence in several mountain plant species (e.g., Martin-Bravo et al., 2010; Alarcón et al., 2012; Blanco-Pastor \& Vargas, 2013; Fernández-Mazuecos et al., 2013).

Domesticated animals feeding on G. lutea do not show preferences for flower color. Despite it, we argue for the importance of considering the effect of domesticated animals on plant conservation and evolution. Livestock shape plant communities and ecosystems through their interaction with particular species (for example López-Sánchez et al., 2014; López-Sánchez et al., 2015). Human activities are known to have many effects on biodiversity (for example, Dirzo et al., 2014). We might have overlooked a potential indirect effect that human could play on diversity conservation and evolution-through the interactions of domesticated mammals with plant communities. Considering livestock effects on plant communities could better our nature understanding and management.

\section{ACKNOWLEDGEMENTS}

The authors thank P Domínguez for field assistance, the reviewers and P Greespoon for comments on the manuscript.

\section{ADDITIONAL INFORMATION AND DECLARATIONS}

\section{Funding}

This study is included in the project "Color polymorphism, geographic variation in the interactions and phenotypic selection. The case of Gentiana lutea L in the Cantabrian Mountains," financially supported by Secretary of State of I+D+I, Ministry of Science and Innovation, Government of Spain (2011-2013). The funders had no role in study design, data collection and analysis, decision to publish, or preparation of the manuscript.

\section{Grant Disclosures}

The following grant information was disclosed by the authors:

Gentiana lutea L in the Cantabrian Mountains.

Secretary of State of I+D+I.

Ministry of Science and Innovation, Government of Spain (2011-2013).

\section{Competing Interests}

The authors declare there are no competing interests. 


\section{Author Contributions}

- Mar Sobral conceived and designed the experiments, performed the experiments, analyzed the data, wrote the paper, prepared figures and/or tables.

- María Losada performed the experiments, analyzed the data, wrote the paper, prepared figures and/or tables.

- Tania Veiga performed the experiments, reviewed drafts of the paper.

- Javier Guitián, José Guitián and Pablo Guitián conceived and designed the experiments, performed the experiments, contributed reagents/materials/analysis tools, reviewed drafts of the paper, wrote the paper.

\section{Field Study Permissions}

The following information was supplied relating to field study approvals (i.e., approving body and any reference numbers):

The Environmental Territorial Service from León, Territorial Delegation of Government of Spain, Regional Government of Castilla and León:12_LE_325_RNA_PuebladeLIllo_INV; Reference: 06.01.013.016/ROT/abp; File number: AEN/LE/103/12.

\section{Data Availability}

The following information was supplied regarding data availability:

The raw data is provided as Data S1.

\section{Supplemental Information}

Supplemental information for this article can be found online at http://dx.doi.org/10.7717/ peerj.1685\#supplemental-information.

\section{REFERENCES}

Agrawal AA, Hastings AP, Johnson MTJ, Maron JL, Salminen J-P. 2012. Insect herbivores drive real-time ecological and evolutionary change in plant populations. Science 338:113-116 DOI 10.1126/science.1225977.

Agrawal AA, Lau JA, Hambäck PA. 2006. Community heterogeneity and the evolution of interactions between plants and insect herbivores. The Quarterly Review of Biology 81(4):349-376 DOI 10.1086/511529.

Ågren J, Hellstrom F, Torang P, Ehrlén J. 2013. Mutualists and antagonists drive amongpopulation variation in selection and evolution of floral display in a perennial herb. Proceedings of the National Academy of Sciences of the United States of America (PNAS) 110:18202-18207 DOI 10.1073/pnas.1301421110.

Agustine DJ, McNaughton SJ. 1998. Ungulate effects on the functional species composition of plant communities: herbivore selectivity and plant tolerance. Journal of Wildlife Management 62(4):1165-1183 DOI 10.2307/3801981.

Alarcón M, Vargas P, Sáez L, Molero J, Aldasoro JJ. 2012. Genetic diversity of mountain plants: two migration episodes of Mediterranean Erodium (Geraniaceae). Molecular Phylogenetics and Evolution 63(3):866-876 DOI 10.1016/j.ympev.2012.02.031. 
Allsup CM. 2014. Overcompensation of Ipomopsis aggregata following ungulate herbivory: getting to the root of it. $\mathrm{PhD}$ Thesis, University of Illinois at UrbanaChampaign.

Anchisi E, Bernini A, Piaggi E, Polani F. 2010. Genziane d'Europa [Gentians of Europe]. Pavia: Verba \& Scripta s.a.s. (in Italian).

Andersson S. 2008. Pollinator and non-pollinator selection on ray morphology in Leucanthemum vulgare (oxeye daisy, Asteraceae). American Journal of Botany 95(9):1072-1078 DOI 10.3732/ajb.0800087.

Asikainen E, Mutikainen P. 2005. Preferences of pollinators and herbivores in gynodioecious Geranium sylvaticum. Annals of Botany 95(5):879-886 DOI 10.1093/aob/mci094.

Bartkowska MP, Johnston MO. 2012. Pollinators cause stronger selection than herbivores on floral traits in Lobelia cardinalis (Lobeliaceae). New Phytologist 193(4):1039-1048 DOI 10.1111/j.1469-8137.2011.04013.x.

Blanco-Fontao B, Quevedo M, Obeso JR. 2011. Abandonment of traditional uses in mountain areas: typological thinking versus hard data in the Cantabrian Mountains (NW Spain). Biodiversity and Conservation 20(5):1133-1140 DOI 10.1007/s10531-011-0016-1.

Blanco-Pastor JL, Vargas P. 2013. Autecological traits determined two evolutionary strategies in Mediterranean plants during the Quaternary: low differentiation and range expansion versus geographical speciation in Linaria. Molecular Ecology 22(22):5651-5668 DOI 10.1111/mec.12518.

Bradshaw HD, Schemske DW. 2003. Allele substitution at a flower colour locus produces a pollinator shift in monkeyflowers. Nature 426:176-178 DOI 10.1038/nature02106.

Burnham KP, Anderson DR. 2002. Model selection and multi-model inference: a practical information-theoretic approach. 2nd edition. New York: Springer-Verlag.

De Jager ML, Ellis AG. 2014. Floral polymorphism and the fitness implications of attracting pollinating and florivorous insects. Annals of Botany 113(2):213-222 DOI $10.1093 / \mathrm{aob} / \mathrm{mct} 189$.

Dirzo R, Domínguez C. 1995. Plant-herbivore interactions in Mesoamerican tropical dry forests. In: Bullock S, Mooney HA, Medina IE, eds. Tropical dry forests. New York: Cambridge University Press, 304-323.

Dirzo R, Young HS, Galetti M, Ceballos G, Isaac NJ, Collen B. 2014. Defaunation in the Anthropocene. Science 345(6195):401-406 DOI 10.1126/science.1251817.

Ehrlich PR, Raven PH. 1964. Butterflies and plants: a study in coevolution. Evolution 18(4):586-608 DOI 10.2307/2406212.

Fernández-Mazuecos M, Blanco-Pastor JL, Gómez JM, Vargas P. 2013. Corolla morphology influences diversification rates in bifid toadflaxes (Linaria sect. Versicolores). Annals of Botany 112:1705-1722 DOI 10.1093/aob/mct214.

Fineblum WL, Rausher MD. 1997. Do floral pigmentation genes also influence resistance to enemies? The W locus in Ipomoea purpurea. Ecology 78(6):1646-1654 DOI 10.1890/0012-9658(1997)078[1646:DFPGAI]2.0.CO;2. 
Frey FM. 2004. Opposing natural selection from herbivores and pathogens may maintain floral-color variation in Claytonia virginica (Portulacaceae). Evolution 58(11):2426-2437 DOI 10.1111/j.0014-3820.2004.tb00872.x.

Galen C. 2000. High and dry: drought stress, sex-allocation trade-offs, and selection on flower size in the alpine wildflower Polemonium viscosum (Polemoniaceae). The American Naturalist 156:72-83 DOI 10.1086/303373.

Gómez JM. 2003. Herbivory reduces the strength of pollinator-mediated selection in the mediterranean herb Erysimum mediohispanicum: consequences for plant specialization. The American Naturalist 162(2):242-256 DOI 10.1086/376574.

Gómez JM. 2005a. Non-additive effects of herbivores and pollinators on Erysimum mediohispanicum (Cruciferae) fitness. Oecologia 143:412-418

DOI 10.1007/s00442-004-1809-7.

Gómez JM. 2005b. Long-term effects of ungulates on performance, abundance, and spatial distribution of two montane herbs. Ecological Monographs 75(2):231-258 DOI 10.1890/04-0722.

Gómez J, Perfectti F, Bosch J, Camacho J. 2009. A geographic selection mosaic in a generalized plant-pollinator-herbivore system. Ecological Monographs 79:245-263 DOI 10.1890/08-0511.1.

Herrera CM. 1984. Seed dispersal and fitness determinants in wild rose: combined effects of hawthorn, birds, mice, and browsing ungulates. Oecologia 63:386-393 DOI 10.1007/BF00390670.

Herrera CM. 2000. Measuring the effects of pollinators and herbivores: evidence for nonadditivity in a perennial herb. Ecology 81(8):2170-2176 DOI 10.1890/0012-9658(2000)081[2170:MTEOPA]2.0.CO;2.

Herrera CM, Castellanos MC, Medrano M. 2006. Geographical context of floral evolution: towards an improved research programme in floral diversification. In: Harder LD, Barret SCH, eds. Ecology and evolution of flowers. Oxford: Oxford University Press, 278-294.

Herrera CM, Medrano M, Rey PJ, Sánchez-Lafuente AM, García MB, Guitián J, Manzaneda AJ. 2002. Interaction of pollinators and herbivores on plant fitness suggests a pathway for correlated evolution of mutualism- and antagonism-related traits. Proceedings of the National Academy of Sciences of the United States of America (PNAS) 99(26):16823-16828 DOI 10.1073/pnas.252362799.

Hesse E, Rees M, Müller-Schärer H. 2007. Seed bank persistence of clonal weeds in contrasting habitats: implications for control. Plant Ecology 190:233-243 DOI 10.1007/s11258-006-9203-7.

IBM Corp. Released. 2011. IBM SPSS statistics for windows. Version 20.0. Armonk: IBM Corp.

International Commission on Illumination. 2004. 15: 2004. Colorimetry. Vienna: CIE Central Bureau.

Irwin RE, Strauss SY, Storz S, Emerson A, Guibert G. 2003. The role of herbivores in the maintenance of a flower color polymorphism in wild radish. Ecology 84(7):1733-1743 DOI 10.1890/0012-9658(2003)084[1733:TROHIT]2.0.CO;2. 
Johnson MTJ, Campbell SA, Barrett SCH. 2015. Evolutionary interactions between plant reproduction and defense against herbivores. Annual Review of Ecology, Evolution, and Systematics 46:191-213 DOI 10.1146/annurev-ecolsys-112414-054215.

Juenger T, Bergelson J. 1997. Pollen and resource limitation of compensation to herbivory in scarlet gilia, Ipomopsis aggregata. Ecology 78:1684-1695 DOI 10.1890/0012-9658(1997)078[1684:PARLOC]2.0.CO;2.

Knight TM. 2003. Effects of herbivory and its timing across populations of Trillium grandiflorum (Liliaceae). American Journal of Botany 90(8):1207-1214 DOI 10.3732/ajb.90.8.1207.

Laínz M. 1982. Mis contribuciones al conocimiento de la flora de Asturias [My contributions to the knowledge of the Asturian flora]. Oviedo: Diputación Provincial de Asturias, Instituto de Estudios Asturianos (CSIC) (in Spanish).

Lakshminarayan S. 2013. Role of carotenoid cleavage dioxygenases in volatile emissions and insect resistance in Arabidopsis. PhD Thesis, University of Western Ontario, Canada.

Lande R, Arnold SJ. 1983. The measurement of selection on correlated characters. Evolution 6(6):1210-1226 DOI 10.2307/2408842.

Lavergne S, Debussche M, Thompson JD. 2005. Limitations on reproductive success in endemic Aquilegia viscosa (Ranunculaceae) relative to its widespread congener Aquilegia vulgaris: the interplay of herbivory and pollination. Oecologia 142(2):212-220 DOI 10.1007/s00442-004-1721-1.

Lev-Yadun S, Gould KS. 2009. Role of anthocyanins in plant defence. In: Gould KS, Davies KM, Winefield C, eds. Anthocyanins: biosynthesis, functions and applications. New York: Springer, 21-48.

López-Sánchez A, Perea R, Dirzo R, Roig S. 2015. Livestock vs. wild ungulate management in the conservation of Mediterranean dehesas: implications for oak regeneration. Forest ecology and management 362:99-106 DOI 10.1016/j.foreco.2015.12.002.

López-Sánchez A, Schroeder J, Roig S, Sobral M, Dirzo R. 2014. Effects of Cattle Management on Oak Regeneration in Northern Californian Mediterranean Oak Woodlands. PLoS ONE 9(8):e105472 DOI 10.1371/journal.pone.0105472.

Losada M, Veiga T, Guitián JA, Guitián J, Guitián P, Sobral M. 2015. Is there a hybridization barrier between Gentiana lutea color morphs? PeerJ 3:e1308 DOI 10.7717/peerj.1308.

Martín-Bravo S, Valcárcel V, Vargas P, Luceño M. 2010. Geographical speciation related to Pleistocene range shifts in the Western Mediterranean Mountains (Reseda sect. Glaucoreseda, Resedaceae). Taxon 59(2):466-482.

McCall AC, Irwin RE. 2006. Florivory: the intersection of pollination and herbivory. Ecology Letters 9(12):1351-1365 DOI 10.1111/j.1461-0248.2006.00975.x.

McCall AC, Murphy SJ, Venner C, Brown M. 2013. Florivores prefer white versus pink petal color morphs in wild radish, Raphanus sativus. Oecologia 172:189-195 DOI 10.1007/s00442-012-2480-z. 
Mitchell-Olds T, Willis JH, Goldstein, DB. 2007. Which evolutionary processes influence natural genetic variation for phenotypic traits? Nature Reviews Genetics 8:845-856 DOI 10.1038/nrg2207.

Narbona E, Buide ML, Casimiro-Soriguer I, Del Valle JC. 2014. Polimorfismos de color floral: causas e implicaciones evolutivas [Flower color polymorphisms: evolutionary causes and implications]. Ecosistemas 23(3):36-47 (in Spanish) DOI 10.7818/ECOS.2014.23-3.06.

Phillips CJC, Lomas CA. 2001. The perception of color by cattle and its influence on behavior. Journal of Dairy Science 84(4):807-813 DOI 10.3168/jds.S0022-0302(01)74537-7.

Renobales G. 2003. Notas acerca del tratamiento de las Gentianaceae para Flora Ibérica [Notes about the treatment of the Gentianaceae for Iberian flora]. Anales del Jardin Botánico de Madrid 60(2):461-469 (in Spanish).

Renobales G. 2012. Gentiana lutea L. In: Castroviejo S, Talavera S, Andrés C, Arista M, Fernández Piedra MP, Gallego MJ, Ortiz PL, Romero Zarco C, Salgueiro FJ, Silvestre S, Quintanar A, eds. Flora Ibérica Vol. XI. Plantas vasculares de la Península Ibérica e Islas Baleares, Gentianaceae-Boraginaceae [Iberian flora Vol. XI. Vascular plants of Iberian Peninsule and Balearic Islands, Gentianaceae-Boraginaceae]. Madrid: Real Jardín Botánico (CSIC) 10-13(in Spanish).

Simms EL, Bucher MA. 1996. Pleiotropic effects of flower-color intensity on herbivore performance on Ipomoea purpurea. Evolution 50(2):957-963 DOI 10.2307/2410871.

Smit C, Ouden JD, Müller-Schärer H. 2006. Unpalatable plants facilitate tree sapling survival in wooded pastures. Journal of Applied Ecology 43(2):305-312 DOI 10.1111/j.1365-2664.2006.01147.x.

Sobral M, Veiga T, Domínguez P, Guitián JA, Guitián P, Guitián J. 2015. Selective pressures explain differences in flower color among Gentiana lutea populations. PLoS ONE 10(7):e0132522 DOI 10.1371/journal.pone.0132522.

Strauss SY, Irwin RE, Lambrix VM. 2004. Optimal defence theory and flower petal colour predict variation in the secondary chemistry of wild radish. Journal of Ecology 92:132-141 DOI 10.1111/j.1365-2745.2004.00843.x.

Strauss SY, Whittall JW. 2006. Non-pollinator agents of selection on floral traits. In: Harder LD, Barrett SCH, eds. Ecology and evolution of flowers. New York: Oxford University Press, 120-138.

Streisfeld MA, Kohn JR. 2007. Environment and pollinator-mediated selection on parapatric floral races of Mimulus aurantiacus. Journal of Evolutionary Biology 20:122-132 DOI 10.1111/j.1420-9101.2006.01216.x.

Struwe L, Albert VA. 2002. Gentianaceae: systematics and natural history. Cambridge: Cambridge University Press.

Tsuchimatsu T, Yoshitake H, Ito M. 2014. Herbivore pressure by weevils associated with flower color polymorphism in Geranium thunbergii (Geraniaceae). Journal of Plant Research 127(2):265-273 DOI 10.1007/s10265-013-0598-7. 
Van der Niet T, Peakall R, Johnson SD. 2014. Pollinator-driven ecological speciation in plants: new evidence and future perspectives. Annals of Botany 113(2):199-211 DOI 10.1093/aob/mct290.

Veiga T, Guitián JA, Guitián P, Guitián JM, Munilla I, Sobral M. 2015a. Flower color variation in the montane plant Gentiana lutea L. (Gentianaceae) is unrelated to abiotic factors. Plant Ecology \& Diversity Epub ahead of print Aug 072015 DOI 10.1080/17550874.2015.1074626.

Veiga T, Guitián JA, Guitián P, Guitián JM, Sobral M. 2015b. Are pollinators and seed predators selective agents on flower color in Gentiana lutea? Evolutionary Ecology 29(3):451-464 DOI 10.1007/s10682-014-9751-6.

Wang H, Conchou L, Bessière JM, Cazals G, Schatz B, Imbert E. 2013. Flower color polymorphism in Iris lutescens (Iridaceae): biochemical analyses in light of plantinsect interactions. Phytochemistry 94:123-134 DOI 10.1016/j.phytochem.2013.05.007.

Warren J, Mackenzie S. 2001. Why are all colour combinations not equally represented as flower-colour polymorphisms? New Phytologist 151:237-241 DOI 10.1046/j.1469-8137.2001.00159.x.

Whittall J, Carlson M. 2009. Plant defense: a pre-adaptation for pollinator shifts. New Phytologist 182:5-8 DOI 10.1111/j.1469-8137.2009.02796.x.

Whittall JB, Hodges SA. 2007. Pollinator shifts drive increasingly long nectar spurs in columbine flowers. Nature 447:706-709 DOI 10.1038/nature05857.

Wise MJ, Hébert JB. 2010. Herbivores affect natural selection for floral-sex ratio in a field population of horsenettle, Solanum carolinense. Ecology 91(4):937-943 DOI 10.1890/09-1373.1.

Zhu C, Yamamura S, Koiwa H, Nishihara M, Sandmann G. 2002. cDNA cloning and expression of carotenogenic genes during flower development in Gentiana lutea. Plant Molecular Biology 48(3):277-285 DOI 10.1023/A:1013383120392.

Zhu C, Yamamura S, Nishihara M, Koiwa H, Sandmann G. 2003. cDNAs for the synthesis of cyclic carotenoids in petals of Gentiana lutea and their regulation during flower development. Biochimica et Biophysica Acta (BBA) 1625(3):305-308 DOI 10.1016/S0167-4781(03)00017-4. 